\title{
Теоретизация Внешней Помитики Китая: Концептуальные Положения в Историческом Континууме ${ }^{1}$
}

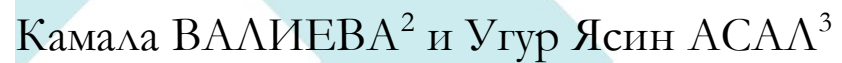

\begin{abstract}
Аннотация
ОАним из основных детерминантов, определяющих внешнеполитическое видение и поведение Китая, а также идейное строение китайского самовосприятия явАяется фактор истории. Внешняя политика Китая и его стратегия подъема характеризуются совокупностью исторической преемственности и изменений в континууме. В Аанной статье была предпринята попытка обосновать илею о том, что внешнеполитическая идентичность и поведение Китая, как возвышающейся или по выражению Генри Киссинджера, возвращающейся силы, определяется его историческим прошлым. Как внутриполитический нарратив, так и внешнеполитическая стратегия глобального возвышения Китая, существующего и развивающегося «в тени своего прошлого», содержит множество ссылок на исторический опыт китайской нации, наиболее полно проецированных в концепции предсеАателя КНР Си Цзиньпина «китайской мечты», осуществление которой, как преАставАяется, Аолжно привести к «великому национальному возрождению» страны и нации. Изложив в ретроспективном порядке процесс развития внешнеполитических подходов Китая с периода учрежАения КНР вплоть АО сегодняшнего Аня, статья преАприняла попытку резюмировать существующие концептуальные подходы к теоретизации внешней политики и феномена глобального возвышения Китая, акцентируя внимание на дихотомии ревизионизма и приверженности статус-кво в отношении структуры мировой системы и разделяя существующие теоретические разработка на Аве категории: конвенциональное и эклектичное теоретизирование. Подчеркивается, что глобальное присутствие Китая и его подъем в контексте воздействия на структуру и принципы существующего международного порядка рассматриваются в диапазоне восприятий Китая как «угроза» и как «возможность».
\end{abstract}

Ключевые Слова: Внешняя Политика Китая, Исторический Континуум, Теории МежАународных Отношений, ГАобальное Возвышение

\section{Theorizing Chinese Foreign Policy: Conceptual Tenets in Historical Continuum}

\section{Abstract}

One of the main determinants that indelibly influence China's foreign policy vision and behavior, as well as the ideational structure of Chinese self-perception is the factor of history. China's foreign policy and its strategy of global rise are characterized by a combination of constancy and change in a continuum. This paper attempted to substantiate the idea that as a rising power or as Henry Kissinger put it a returning power China's foreign policy identity and behavior are determined by its historical past. China exists and evolves in the shadow of its past experiences. Both the domestic political narrative and the foreign policy strategy of a rising China contain numerous references to the historical experience of the Chinese nation. This appeal to history is most fully projected in Xi Jinping's "Chinese Dream" concept, the realization of which is supposed to accelerate the "great rejuvenation of the Chinese nation". By outlining the evolution of China's foreign policy approaches in a retrospective manner this paper summarizes the existing conceptual accounts of Chinese foreign policy and the phenomenon of China's global rise. In doing so the paper differentiates existing theoretical approaches into two categories of conventional and eclectic theorizing with a specific focus on the dichotomy of "revisionism" and "adherence to the status quo" in relation to the existing structure and principles of the international system.

Key Words: Foreign Policy, China, Historical Continuum, International Relations Theories, Global Rise

\section{Atıf İçin / Please Cite As:}

Valiyeva, K. ve Asal, U. Y. (2021). Теоретизация внешней политики китая: Концептуальные положения в историческом континууме. Manas Sosyal Arasstırmalar Dergisi, 10(2), 1389-1408.

Geliş Tarihi / Received Date: 04.02.2021

Kabul Tarihi / Accepted Date: 25.02.2021

\footnotetext{
${ }^{1}$ Аанная статья является частью исследовательского проекта под названием «Глобальный Подъем Китая и Его Влияние на Центральноазиатские Тюркские Республики: Многомерное и Междисциплинарное Исследование», выполняемого при подлержке Факультета Политологии и Международных Отношений Стамбульского Коммерческого Университета и Программы Подлержки Научных и Технологических Исследовательских Проектов при Стамбульском Коммерческом Университете. 2 Dr. Kamala VALIYEVA - İstanbul Ticaret Üniversitesi, Rektörlük Proje Yönetimi Ofisi, kamala.valiyeva@istanbulticaret.edu.tr

iD ORCID: 0000-0002-7551-8555

${ }^{3}$ Dr. Uğur Yasin ASAL - İstanbul Ticaret Üniversitesi Siyaset Bilimi ve Uluslararası İlişkiler Bölümü, uyasal@ticaret.edu.tr

(D) ORCID: 0000-0003-1567-9186
} 


\section{Введение}

С окончанием холодной войны и распадом биполярной системы межАународных отношений Китайская Народная Респуболика (КНР) стала наиболее важной возвышающейся силой, сумевшей переместиться с периферии в центр межАународной системы. Растущее присутствие и вАияние Китая отчетливо ощущается во всей Аинамике изменения межАународных отношений и почти на всех континентах Земли. В настоящее время исследования международных отношений, в течение последних тридцати мет сфокусировавшие свое внимание на измерение степени и механизмов влияния мира на Китай, перевели свой исследовательский акцент на понимание того, как Китай влияет на мир, и осмысление феномена глобального возвышения Китая (Shambaugh, 2013, 4). ОАнако Аля поиска и постижения основ глобального подъема Китая и вместе с тем сущности внешнеполитического подхода страны следует исходить не только из текущего процесса межАународных отношений, а прибегнуть к ретроспективному анализу китайской внешней политики в свете элементов переменчивости и континуума, свойственных вылвинутым на различных исторических этапах внешнеполитическим доктринам и концептуальным положениям.

С момента провозглашения КНР в 1949 году китайская внешняя политика претерпела существенные трансформации поА воздействием внешних и внутренних факторов. В рамках этой трансформации внешнеполитическая ориентация и подходы Китая также подверглись неоднократному пересмотру. Аругими словами, в пределах кажАого периода исторической эволюции внешней политики Китая стратегический подхоА и его концептуальное оформление, внешнеполитические приоритеты и видение миропорядка менялись в зависимости как от внутренних, так и внешних (глобальных и региональных) перемен.

В Аанной статье, нацеленной на рассмотрение исторического процесса изменения внешнеполитического подхода Китая, обсужАаются периоды указанного процесса трансформации, основные положения и особенности внешнеполитических Аоктрин, разработанных в пределах каждого этапа, а также проекция основных идей и принципов на текущий процесс возвышения Китая с глубокими региональными и глобальными послеАствиями. Основная идея, выдвигаемая авторами статьи, заключается в том, что внешнеполитическая идентичность и поведение Китая, а также вся конструкция его внешней активности осуществАяется и развивается поА воздействием исторического прошлого. Исторический опыт, метафорически определенный как «тень прошлого» или «тирания прошлого» (Jenner, 1995; Fairbank, 1968), как наиболее существенный детерминант сущности китайского видения мира и своего места в нем, образует фундамент предпринимаемой в статье попытки ретроспективного анализа внешней политики Китая. Наиболее наглядным проявмениям фактора истории в теоретизации внешней политики Китая и его стратегии возвышения является ссылка на исторический опыт «столетия унижения» как во внешнеполитической Аоктрине в целом, так и в концепции «китайской мечть», на которой зиждется стратеги подъема и осуществление которой должно привести к «великому национальному возрождению».

В теоретико-методологическом плане учитывая недостаточность и ограниченность объяснительного потенциала традиционных теорий межАународных отношений в поисках подходящей концептуаАьной основы ААя осмысления китайской внешней политики и глобального подъема статья опирается на утверждение о необходимости в синтезирующих разработках, межпарадигмальных и эклектических подходах. В этом отношении теоретизация внешней политики Китая производится как в рамках конвенциональный теорий межАународных отношений (неореализм, неолиберализм, конструктивизм), так и эклектических проходов (теория перехода власти, теория английской школы межАународных отношений (Аиберальный реализм) и неоклассический реализм), которые могут инициировать новые Аискуссии о сущности власти и ее трансформации.

\section{Китайская Внешняя Политика: История, ИАеи и Принципы}

\section{Период до Коммунистической Революции}

С точки зрения анализа истории китайской государственности и внешней политики периоА межАу Первой опиумной войной (1840-1842), по итогам которой западные Аержавы-победители получили существенные торговые привилегии, и провозглашением КНР в 1949 году с консолиАацией у власти Коммунистической партии Китая (КПК) имеет важнейшее значение Аля 
полного понимания сущности китайской внешней политики и феномена китайского возвышения, наблюдаемого в наши дни (Zhu, 2013, 119).

В этом историческом процессе наиболее устойчивой константой явАяется китайское само и мировосприятие. Так, в центре китайского государственного самовосприятия находилось представление о себе, как о «благословенной небесами царстве», а также величайшей Аержаве и цивилизации мира. Соответственно, в классическом китайском мировидении географическая область, охватываемая Китаем, именовалась «Поднебесной империей», изображаемой в качестве центра мира. Китай, как конкретизация этого представления, в этой конструкции именовался «Срединной страной» (Xuetong, 2013, 216-221; Бычкова, 2014, 54). В этом отношении Китайская империя занимала центральный пояс трех равноудаленных концентрических кругов. Второй пояс, опоясывающий Срединное царство, образовывали колонии и зависимые государства (такие как Япония, Корея и Вьетнам), которые воспринимались как подчиненные составляющие в иерархии конфуцианского мира. Народы и иноземные страны, удаленные от этих двух поясов и не ведавшие о китайской цивилизации, назывались варварами и могли строить с Китаем только неравноправные отношения вассального характера (Miller, 2017, 21). К XIX веку Китайская империя обладала огромной мощью, сравнимой с доминирующими державами той эпохи как с точки зрения демографического потенциала, так и в плане процветающей экономики и растущего богатства. В контексте азиатского континента это превосходство было особенно очевидным, так как располагающий широким господством наА сушей и морем Китай обладал потенциалом конструирования регионального порядка, в том числе цивилизационного.

Середина XIX века - это переломный период Аля китайской государственности, который ознаменовал как кульминацию могущества Китайской империи, которая постоянно расширялась и распространяла свое влияние на близлежащие регионы, так и начало упалка этого могущества, продолжавшегося вплоть до середины ХХ века и вошедшего в китайскую историографию как «столетие унижения» (Garver, 2016). Так, Китай во время правления династии Цин, расширяя свое имперское присутствие в северном и западном направлении присоединил Тибет, Монголию и большую часть Центральной Азии (Восточный Туркестан или в нынешнем понимании Синьцзян, что означает «новая граница»). Тесные связи Китайской империи с близлежащими государствами Юго-Восточной Азии от Бирмы до Корейского полуострова опирались на так называемую «систему Аани» ${ }^{4}$, предполагающее Аоминирующее превосходство Китая наА «некитайскими» элементами регионального порядка (иерархии). Эта совокупность Аипломатических и торговых отношений, которая символически предполагала подчинение китайскому императору, имела историческое значение, особенно с точки зрения торговли, так как представляла собой набор институтов, правиц и Аипломатических норм, которые регулировали отношения Китая с внешним миром до краха империи в конце XIX века (Zhang, 2009).

Но к середине XIX века этот региональный порядок, основанный на центральном положении и влиянии Китайской империи, начал разрушаться. Опиумные войны между Великобританией и Китайской империей положили конец системе Аани, а с подписанием Нанкинского договора в 1842 году в международных отношениях Китая начался «период неравноправных соглашений». ${ }^{5}$ В ряде соглашений, подписанных между Китаем и различными западными державами, Россией и Японией в период после военного поражения, содержались односторонние условия, требовавшие отказ Китая от своей территории, выплату компенсации державам-победителям, открытие своих портов Аля иностранных держав и предоставление им неограниченных торговых привилегий.

\footnotetext{
${ }^{4}$ Идеи, лежащие в основе происхождения, структуры и функционирования «системы дани», опираются на ценности и верования Аревнего Китая. В этом смысле утвержАается, что начиная с Аинастии Хань (206 г. Ао н. э. - 220 г. н. э.) Китай разработал систему Ааннического отношения ААя регулирования торговли и дипломатии со своими сосеАями. БуАучи неоднообразной и меняющейся конструкцией на протяжении всей истории Китая, система Аани тем не менее составАяла основу Китае-центричного порядка в Юго-Восточной Азии. Аля дополнительной информации см.: Fairbank, J. K. (Ed.) (1968). The Chinese World Order: Traditional China's Foreign Relations. Cambridge: Harvard University Press; Kang, D. (2010). East Asia before the West: Five Centuries of Trade and Tribute. New York: Columbia University Press.

5 «Периол неравноправных соглашений», который к началу XX века привел к росту китайского национализма и антиимпериализма и использовался Аля характеристики потери суверенитета, стал, пожалуй, еАинственной точкой соприкосновения двух противоборствующих политических сил на тот период - Китайской Националистической Партии (ГоминьАан) и Коммунистической Партией Китая. Сегодня к Аанному термину часто обращаются также в сочетании с нарративом «века унижения», в качестве наглядного отображения негативных последствий потери былого могущества и вечной угрозы, исходящей от иностранных держав.
} 
Помимо борьбы с внешними силами, с 1850 по 1864 годы Китай также стал ареной кровавой гражАанской войны, известной в истории как Тайпинское восстание (Грачиков, 2015, 141).

Таким образом, в результате этих Авух исторических событий ослабевающая власть Китайской империи стала очевидной и Китай вступил в самый мрачный периоА своей истории. После краха династии Цин в 1911 году страна подверглась японской оккупации. Кровавая гражАанская война межАу правительством Китайской Республики во главе с Китайской Националистической Партией (ГоминьАан) и Коммунистической Партией Китая (КПК), Алившаяся с 1920-х до 1949 года, завершилась Коммунистической Революцией в Китае, в результате которой контроль наА материковым Китаем перешел к коммунистам, и в 1949 году была создана Китайская Народная Республиика (Lew \& Leung, 2013, 9-12).6

\section{Период преАсеАательства Мао Цзэдуна}

Коммунисты во главе с Мао Цзэдуном, в 1949 году основавшие КНР, возглавили страну, которая была разрушена войнами и потрясениями. В своем стремлении восстановить Китай после столетия разрушений, коммунисты разработали нарратив, призывающий «вечно помнить историческое прошлое национального унижения», исходя из убеждения, что «чувство унижения Аолжно способствовать национальному возрожАению». Эффект чувства «национального унижения», который систематически обновцяется в исторической памяти и, таким образом, используется в качестве важного эмемента в построении китайской национальной идентичности, по-прежнему остается важным ориентиром в рамках Аискурса «великого национального возрождения».

Политические, экономические и идейные истоки феномена возвышающегося Китая в сегодняшней мировой системе необходимо искать именно в вышеизложенном историческом процессе расцвета и упаАка китайской государственности, который в значительной степени наложил свой отпечаток также на последующие этапы эволюции Китая второй половины XX века. Отрезок времени, начавшийся с образования Китайской Народной Республики и Алившийся до окончания Холодной Войны, можно изучить путем разделения на пять соответствующих периодов, каждый из которых явАяется важнейшим индикатором изменений и обновлений в китайской внешнеполитической Аоктрине, конкретизации цемей и приоритетов в отношении внешнего мира.

Так, в период с 1949 года Ао конца 1950-х годов придерживавшийся одностороннего внешнеполитического подхода Китай был в значительной степени изолирован от внешнего мира и находился в зависимости от подАержки Советского Союза. В условиях биполярного мира холодной войны Китай, принимавший активное участие в борьбе с мировым империализмом, стаА частью социалистического блока во главе с СССР. Именно в этот периоА произошло подписание Аоговора о Аружбе, единстве и взаимопомощи (1950г.) межАу Китаем и СССР под руководством Мао Цзэдуна и, как следствие, возникновение политико-идеологического и стратегического союза. Более того, в целях восстановления промышленности и сельского хозяйства, Китай прибегнул к обширной финансовой и технологической подхержке СССР и принял советскую модель развития (Грачиков, 2015, 206). Кроме того, СССР сыграл важную роль в разработке основ китайской ядерной программы. ОАнако проблемы, которые со временем возникли межАу Москвой и Пекином, к концу 1950-х годов привели к разрыву двусторонних отношений.

Как следствие разрыва советско-китайский отношений «оАносторонний подхоА» в китайской Аипломатии потерял действенность (Fingar, 2016, 119). С конца 1950-х - начала 1960-х гг. Китай, постепенно отошедший от одностороннего подхода и, следовательно, от внешней политики, ориентированной на СССР, начал разрабатывать независимую внешнеполитическую Аинию, но при этом сохраняя свой идеологический курс построения социализма. По сути, китайская внешняя политика, изначально основанная на советской модели марксистско-ленинской илеологии, стала приобретать отличительные черты или китайскую специфику именно в этот периоА. В годы холодной войны развитие отношений со странами Азии, Африки и Аатинской Америки, а также

\footnotetext{
6 Правительство Китайской Республики было вынуждено сосредоточить свою власть на острове Тайвань. С этого момента между Авумя берегами Тайваньского пролива была прочерчена политическая и военная разделительная линия. И Китайская Республика на Тайване, и материковая Китайская Народная Республика продолжают формально претендовать на статус законного правительства всего Китая. Факт того, что межАу Авумя китайскими государствами не было подписано мирного соглашения, вызывает споры о завершении гражданской войны.
} 
сочетание борьбы против ревизионизма (против СССР) с борьбой против империализма (против США) состав яяли основные черты этого периода (Yllmaz, 2015, 83). В том контексте, столкнувшись с ситуацией противостояния с обеими сверхдержавами или феноменом «Авойного врага», Пекин инициировал стратегию «третьего фронта», которая предусматривала перемещение промышленных мощностей страны во внутренние регионы (Shambaugh, 2013, 38-39).

Несмотря на ухудшение отношений с СССР Китай установил Аипломатические отношения со многими развивающимися странами и сформулировал пять принципов «мирного сосуществования», которые стали характерной чертой китайской внешней политики в последующие этапы. Это принципы взаимного уважения суверенитета и территориальной целостности, взаимного ненападения, невмешательства во внутренние дела, равенства и взаимной выгоды, а также мирного сосуществования. Считацось, что эти принципы составляют прочную основу дружественных отношений межАу Китаем и Аругими государствами и были закреплены в Конституции КНР. С таким видением основ межгосударственных отношений Китай стал одним из лилеров Авижения неприсоединения, отвергающего членство в каком-либо военно-политическом блоке, что составило основу установления тесных Аипломатических отношений со странами третьего мира в соответствии со своими собственными интересами (Olimat, 2010; Taylor, 2010; Roett, 2010).

На фоне развития и расширения отношений со странами развивающегося мира Китай разработал своеобразный внешнеполитический подход, который был основан на теории «трех миров», выдвинутой Мао Цзэдуном (Fingar, 2016, 129). В отличие от западного мировидения, который делиц мир на капиталистические, социалистические и развивающиеся страны и подчеркивац биполярность мировой системы, теория «трех миров» Китая рассматривала СССР и США, как Аве сверхлержавы в качестве «отдельного мира», части которого проводят гегемонистскую политику и пытаются навязать свою волю остальному миру. Соответственно, развитые капиталистические страны и коммунистическое страны Восточной Европы, сушествовавшие пол контролем и давлением двух сверхлержав, образовывали «второй мир». А развивающиеся страны Азии, Африки и Аатинской Америки, которые вели борьбу за независимость против гегемонии и империализма, составляли яАро «третьего мира». СлеАует подчеркнуть, что подход «трех миров» был сформулирован в то время, когда Китай находицся в напряженных отношениях как с СССР, так и с США, и столкнулся с необходимостью обоснования собственных политических целей на мировой арене.

В результате «культурной революции» (1966-1976) в Китае произошла радикализация в том числе и во внешнеполитической минии страны. Взаимное недоверие в отношениях с СССР усилилось, разогрев проблему «илеологического противостояния» вследствие возникновения уникального и свойственного только Китаю социализма (Торбаков, 2016). Провозглашение в 1968 году Аоктрины Брежнева, мегитимировавший интервенцию СССР в Аругие социалистические страны, было воспринято в Пекине как угроза, что привело к осознанию необходимости пересмотра и отказа от политики изоляционизма, принятой в период «культурной революции». Так, на фоне углубления китайско-советской враждебности в результате короткого пограничного конфликта 1969 года, Китай вступил в процесс сближения с США. Это происходило параллельно с открытием Китая внешнему миру и начатыми экономическими реформами. Аействительно, одним из самых важных событий этого периода было решение Мао Цзэдуна сблизить отношения с США. Китай предложиц США подписать соглашение, основанное на пяти принципах мирного сосуществования, и в феврале 1972 года состоялась встреча президента США Ричарда Никсона и Мао Цзэлуна. Установление полноценных контактов с развитыми странами капиталистического мира на основе принципа признания Китая создало основу Аля формирования нового вектора китайской внешней политики. Тот факт, что Китайская Народная Республика утвердила членство в ООН в 1971 году, стал важным фактором продвижения политики открытия Китая внешнему миру.

\section{Период политики экономических реформ и открытости внешнему миру}

Период с конца 1970-х до конца 1990-х годов чрезвычайно важен с точки зрения понимания внешнеполитической идентичности Китая и нынешнего феномена глобального подъема, поскольку в этот период была определена новая парадигма отношений между Китаем и внешним 
миром. Эта парадигма, основы которой были заложены с конца 1970-х годов, в первую очередь проистекает из динамики внутренних изменений Китая. Так, реформистская группа во главе с $А э н$ Сяопином, пришедшая к власти вместо консервативно настроенного Мао, начала реализовывать Аискурс и политику «открытости внешнему миру и экономических реформ», объявленных в 1978 г.

В отличие от эпохи Мао, новое руководство Китая сместило стратегический приоритет страны с илеологической борьбы на экономическую. Политика «открытости Аля внешнего мира и реформ» была принята Аля увеличения иностранных инвестиций и усиления темпов развития (Scobell, 2020). Аэн Сяопин, руководивший страной с 1978 по 1992 гоА, утвержАал, что Китаю следует оставаться в тени во внешней политике и сосредоточиться на регулировании своих внутренних Аел. В этот период происходит нормализация отношений со многими странами мира и построение новой внешнеполитической доктрины, предусматривающей отказ от раАикальной илеологической пропаганды. Важное значение приобрела экономическая составляющая в межАународных отношениях, подчеркнуто развитие взаимовыгодных механизмов двустороннего и многостороннего взаимодействия. Аругими словами, Аля Китая экономическое измерение обрело приоритет наА политическим в Авусторонних отношениях, основанных на принципе равенства.

С этого периода идейным ядром китайской внешнеполитической Аинии становится концепция «мирного развития», основанная на конфуцианских принципах (Shaohua, 2006; Bijian, 2005). Такое понимание внешней политики сформировалось в основном в середине XX века и оценивалось как расширение подхода, основанного на пяти классических принципах мирного сосуществования, упомянутых выше. Согласно этому подходу, также известному как «мирное возвышение», основной потребностью Китая Аля Аостижения основных целей и интересов во внешней политике является обеспечение региональной и межАународной стабильности и непрерывности доступа к глобальным финансовым и технологическим возможностям. Китайское руководство стало выражать убежденность, что мирный рост и подъем возможны только в том случае, если Китай становится частью международных конфликтов. Таким образом, концепция «мира и развития» стал проявлением необходимости перехода от теоретических догм марксизма к государственному капитализму и объективной реацьности глобализации (Bekkevold \& Ross, 2016: 352).

В общих чертах, внешнеполитический подход Китая, принятый со времен Аэн Сяопина, основан на формуле «скрывай свою силу, жди своего часа» (Shambaugh, 2013, 15-16). Так, начиная с

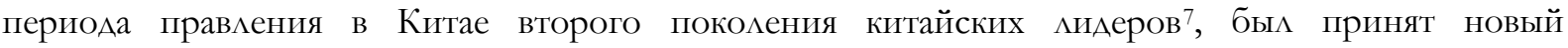
внешнеполитический подход, предусматривающий осторожность, прагматичность, ориентированность на экономические выгоды и избегание прямой конфронтации с внешними силами, а также недопущение или смягчение илеологических и военно-политических противостояний в межгосударственных отношениях. С этого периода (в особенности с периода правления Цзян Цзэминя) Китай принял стратегию аккумулирования своего внутреннего экономического потенциала в соответствии с целью глобального роста в скцаАывающемся многополярном миропорядке.

Однако события на площади Тяньаньмэнь в июне 1989 года стали важным переломным моментом во внутренней и внешней политике Китая. Кроме того, с распадом коммунистических режимов Восточной Европы и Советского Союза, исчезновением социалистического блока и крахом биполярной глобальной системы у Китая возникла необходимость переосмысления своего виления мира и отношений с внешним миром (Yilmaz, 2015). Китайский режим оказался переА экзистенциональной потребностью осмыслить динамику распада Советского Союза с тем, чтобы не повторить его участь, и в этом плане признал приоритетность сосредоточения внимания на экономическом развитии, которое последовало по пути пересмотра социализма в направлении его наполнения Аиберально-реформистскими илеями (Иванов, 2016, 61).

\footnotetext{
7 Выражение «китайское руководство второго поколения» используется Аля обозначения политического режима, установившегося после смерти Мао в 1976 году и продолжавшегося до ухода Аэн Сяопина от власти в результате событий на площади Тяньаньмэнь в 1989 году. В этой классификации китайские Аидеры во главе с Мао Цзэлуном составляли «первое поколение», руководство во главе с Цзян Цзэминем (1993 по 2003) - «третье поколение», а Ху Цзиньтао (2003-2012 годы) - «четвертое поколение». Группа Аилеров во главе с Си Цзиньпином, пришедшая к власти в 2012 году, называется «пятым поколением» китайских лидеров. См.: Во, Z. (2016). China’s Fifth-Generation Leaders. Characteristics of the New Elite and Pathways to Leadership. In R. S. Ross \& J. I. Bekkevold (Eds.). China in the Era of Xi Jinping. Domestic and Foreign Policy Challenges (pp. 47-118). Washington, DC: Georgetown University Press.
} 
Так, Китай под руководством Цзян Цзэминя (1993-2003) придерживался «сдержанной» (или ненапористой) внешнеполитической стратегии как продолжение вышеуказанной формулы Аэн Сяопина и сосредоточился на внутреннем экономическом росте. БАагодаря этому китайская экономика начала быстро расти, и страна постепенно стала мировой фабрикой, что привело к превращению Китая в наиболее важный центр мировой экономики. В этом контексте китайские руководители неоднократно подчеркивали, что Китай не претендует на роль глобальной политической Аержавы. Иными словами, Китай занял «скромную» минию так называемой «половинчатой силы» в межАународных отношениях (Shambaugh, 2005, 306; 2013).

В то время как в годы холодной войны Китай выступац за коренную перестройку системы межАународных отношений, подчеркивая угрожающее вАияние империализма, гегемонизма и колониализма на осуществление принципов мирного сосуществования, в периоА после холодной войны он сосредоточил внимание на обновлении существующего межАународного порядка и своих отношений с остальным миром. Ревизия мирового порядка, по убежАению Китая, не Аолжна была вызывать системное колебание, и обновляющийся мировой порядок Аолжен был Аишь учесть растущую материальную мощь Китая, который мог бы занять в этом новом мире позиции, пропорциональные этому росту (Үе, 2019: 94). Аругими словами, произошел переход от илеологической убежденности, направленной на разрушение системы, к более прагматичному подходу сохранения ее внутреннего содержания с некоторыми корректировками (Yllmaz, 2015, 8385; Scobell, 2020).

Такое видение будущего мирового порядка зиждется на вере в то, что мир должен развиваться в направ ении многополярности, которая стала важной точкой корреляции и соответствия в отношениях с постсоветской Россией. По сути, это общее видение мирового порядка проявилось в создании Шанхайской Организации Сотрудничества (ШОС), которая явАяется важной институциональной проекцией постсоветского российско-китайского партнерства и значительной платформой Аля военного сотрудничества в Центральной Азии (Аукин, 2020).

Несмотря на неприемлемость Китаем западной убежденности в том, что однополярность явАяется единственно возможной формулой мирового порядка, Пекин воспользовался основными институтами и нормами пост-биполярного мирового порядка как возможностью Аля укрепления и развития своей экономики. Таким образом, в 2001 году Китай стал членом ВТО, укрепиц свои отношения со странами АСЕАН в Азиатско-Тихоокеанском регионе и преуспел в установлении глубоких структурных, экономических и политических связей с разАичными континентами и регионами мира. В этом контексте подчеркивается, что Китай не пытается добиться политической гегемонии или доминирующего политического превосходства, особенно в отношениях с развивающимися странами, а основан на принципе равенства и взаимной выгоды (Wen, 2004).

ОАнако глобализация, а также ценности, нормы и институты, которые она предусматривает, имеют Аля Китая функциональный характер. В этом смысле китайский национализм и глобализация рассматриваются как явления, Аополняющие Аруг Аруга. С одной стороны, Китай АОАжен принять экономическую глобализацию (экономические реформы и открытость), когда это необходимо, с тем чтобы превратиться в сильное и процветающее государство. В этом контексте Китай оценивает экономическую глобализацию с односторонней точки зрения, интерпретируя ее в категориях «госуАарство-центричной» глобализации или глобализации, служащей «укреплению государства». С Аругой стороны, он Аолжен предотвращать всевозможные идеологические эмементы глобализации. Таким образом, внешняя политика Китая в эпоху глобализации продемонстрирова^а противоречивость понимания интеграция Китая в межАународную систему и углубление отношений взаимозависимости, которые как усиливают, так и ограничивают суверенитет Китая (Kim, 2006, 298).

\section{Период становления Китая как новой сверхдержавы}

В рамках периода, начавшегося с начала 2000-х годов и продолжающегося до сегодняшнего Аня, происходило становление Китая как новой сверхдержавы. Основываясь на сочетании быстрого роста экономической мощи и распространении китайского вАияния на всех континентах мира, как посредством рычагов экономического воздействия, так и использования разАичных инструментов мягкой силы, Китай превратился в один из полюсов межАународной системы в контексте геополитического и геоэкономического вАияния. В этом плане Китай по-прежнему 
считает, что нынешнюю структуру международной системы следует подАерживать на основе принципов мирного сосуществования. Основываясь на этом классическом подходе, Китай, выАвинувший идею «гармоничного мира» Аля «общего развития» во всем мире, придерживается стратегии, основанной на Авух основных концепциях внешней политики, таких как «мирное возвышение» (периоА Ху Цзиньтао) и «Китайская мечта» (период Си Цзиньпина).

Концепции «гармоничного мира» и «мирного возвышения», выдвинутая Ху Цзиньтао (20032012) в качестве основного видения внешней политики Китая, исходит из тезиса, что Китай - это развивающаяся страна, рост и возвышение которого ориентировано в основном на улучшение жизни и благосостояния собственного населения и экономики (Vision and Actions, 2015). Следовательно, «мирный подъем» Китая не влечет за собой отрицательное воздействие на Аругие государства, не нацелено на разрушение существующего баланса сил и не ставит под угрозу устоявшийся порядок в межАународной системе (Suettinger, 2004).

По мнению Ху Цзиньтао, подход «гармоничного мира» Аолжен иметь четыре основные характеристики: (1) эффективная многосторонность, в которой Организация Объединенных Наций играет сильную роль, (2) развитие механизма коллективной безопасности, (3) процветание Аля всех на основе взаимной выгоды и сотрудничества и (4) укрепление толерантности и диалога межАу различными цивилизациями. Подобно подходу «мирного подъема», в виАении «гармоничного мира» Китай пытается создать имидж и восприятие того, что его подъем не будет угрозой, что Китай не намерен превращаться в гегемонистскую Аержаву или что он не нарушит текущий мировой порядок (Shambaugh, 2016, 269; Vision and Actions).

По словам Ху Цзиньтао, отношения мира, развития и сотрудничества в нынешней мировой системе предостав яют беспрецедентную возможность Аля разных стран мира жить вместе в мире и гармонии. На самом деле считается, что международное сообщество должно работать вместе и прилагать усилия Аля построения гармоничного мира в целях достижения прочного мира и всеобщего процветания. В качестве продолжения этого убеждения нынешний глава Китая Си Цзиньпин в 2012 году представиц концепцию «Сообщества Общей Судьбы» (Zhang, 2018). Это понимание мировой системы и места Китая в ней Аалее оформилось в концепцию «китайской мечты», разработанной со стороны пятого поколения китайских мидеров во главе с председателем Си Цзиньпином. Концепция, оформленная вокруг мечты о великом возрождении китайской нации, состоит из трех основных компонентов: (1) сильное государство всеобщего благосостояния, (2) национальное возрождение, (3) национальное/социальное счастье (Peters, 2017, 1300; Miller, 2019).

Подчеркивая, что Коммунистическая партия Китая явАяется Аокомотивом «Китайской мечты», это видение рассматривается как единственный способ построения китайского социализма и возрождения китайской нации. Ожилается, что реализация Китайской мечты превратит страну в богатое, мощное, демократическое, цивилизованное, гармоничное, модернизированное социалистическое государство, и эта цель будет реализована к 100-летию образования КНР в 2049 ГOAY.

Таким образом, конечная цель нынешней внешней политики и большой стратегии Китая это Аобиться «национацьного возрождения» и, таким образом, реализовать «китайскую мечту». Это означает «строительство современной социалистической страны, богатой, могущественной, Аемократической, цивилизованной и гармоничной». На первом этапе плана развития, определенного Си, который продлится до 2035 года, Китай стремится стать мировым Аилером в области инноваций и обладать большей «мягкой силой». На втором этапе, который проАлится Ао 2050 года, Китай станет «процветающей, сильной, Аемократической, культурно развитой, гармоничной и красивой страной» (Vision and Actions; Peters, 2017, 1300). В соответствии с этими цемями, устав КПК был пересмотрен, и был принят дискурс о «построении китайского социализма Аля новой эпохи», который приАает иАеологическую мегитимность современной политике и вАасти КПК (Scobell, 2020).

Путь к Аостижению цели национального возрождения Аежит через расширение и укрепление экономического сотрудничества, которое Аолжно охватить весь евразийский континент. Это видение, направленное на повышение благосостояния китайского общества, касается внутренней и внешней политики в целом. Такое понимание подразумевает, что реализация «китайской мечты» и 
мирное развитие Китая зависит в том числе от развития окружающих его стран. Соответственно считается, что виление, предлагаемое Китаем миру, служит всеобщему благу (Peter, 2016, 942, 956).

Вера в уникальную роль Китая в мире занимает важное место в подходе «Китайской мечты». Так, Китай изображается как сила, которая верит в мирное развитие и межАународное сотрудничество, гармоничный мир, а его традиционные идеалы и ценности несут пользу всему мировому сообществу. Стремление к «богатству и развитию» сосреАоточено как на экономических, так и на социально-культурных («мягкая сила») и военно-политических («жесткая сила») элементах. Так, по мнению Си Цзиньпина, «Китай Аолжен сохранить связь межАу богатой страной и сильной армией и стремиться к построению консолидированной национальной обороны, чтобы осуществить национальное возрождение» (Kai \& Huiyun, 2013; Miller, 2017, 30). Таким образом, Си отказался от сдержанного (неактивного) внешнеполитического подхода. Первые признаки к переходу к про-активной внешней политике возникли в призыве Си к «новой модели отношений межАу великими Аержавами». Китай также стал уделять приоритетное внимание «Аипломатии соседства» (Аипломатии ближнего зарубежья) и начац формировать конкретную политику, чтобы превратить свой экономический вес в региональное милерство (Yan, 2014).

Исходя из такого виления внешней политики, Китаю удалось стать первой экономикой в мире и одной из ведущих стран-инвесторов в течение первого Аесятилетия ХХІ века. В этот период Китай развиц способность применять основные положения своего уникального внешнеполитического виления в конкретных глобальных проектах (Rolland, 2017). В этом контексте Си Цзиньпин разработал различные региональные и глобальные инициативы и инициирова^ партнерские отношения, такие как Инициатива «ОАин пояс, один путь» (в которую входят проекты Экономический Пояс Шелкового Пути и Морской Шелковый Путь XXI века), Азиатский Банк Инфраструктурных Инвестиций и Региональное Всеобъемлющее Экономическое Партнерство. По мнению Китая, исходя из вышеупомянутого подхода, участие государств Евразии в проектах, предусматривающих возрождение исторического Шелкового пути, будет способствовать взаимной выгоде и всеобщему процветанию. Китай подчеркивает, что реализация проекта нового Шелкового пути не только обеспечит развитие инфраструктуры регионов вдоль маршрутов, предусмотренных проектом, но и трансляцию понимания «сообщества общей судьбы» и «гармоничного развития» в государства всего евразийского континента (Dian \& Menegazzi, 2018, 128).

\section{ГАобальный Подъем Китая в Свете Теорий МежАународных Отношений: Аихотомия Ревизионизма и Приверженности Статус-Кво}

В центре внимания академических исследований находится поиск теоретической основы, которая позволит понять, объяснить и спрогнозировать внешнюю политику Китая и ее глобальный подъем. В целом влияние Китая и его подъем в контексте влияния на структуру международного порядка рассматривается в диапазоне восприятий Китая как «угроза» и как «возможность» (Callahan, 2005).

Учитывая китайское видение международного порядка и особенности его эволюции, изАоженные выше, существуют разАичные подходы и понимания внешнеполитических намерений Китая. По словам Аи Куан Ю, «Китай намерен стать величайшей державой в мире. Более того, в отАичие от Аругих развивающихся стран Китай стремится к тому, чтобы его воспринимали именно как «Китай», а не как участник западного кагеря» (Allison et al., 2012, 41). По словам Генри Киссинджера, «Китай считает себя не возвышающейся, а возвращающейся державой. Так, Пекин рассматривает появцение могущественного Китая с влиянием в экономических, культурных, политических и военных вопросах как возврат к естественному положению, а не как «анормальный» вызов нынешнему мировому порядку. Это вопрос исторической преемственности и рассматривается как проявление характеристики Китая быть цивилизацией не только бесконечной, но и «без начала» (Kissinger, 2012). Киссинджер напоминает, что эпосы «Желтый император» и «История трех королевств», которые занимают важное место в идейном строении Китайского самовосприятия, обращаются к процессу погружения китайской цивилизации в хаос и возрожление, резюмируя эту неизменную диалектику: «разделенная империя Аолжна быть вновь объединена, объединенная империя должна быть вновь разделена». (Kissinger, 2012: 27-31). Аругими словами, в исторической памяти Китая, который пережил многие периоды внутренних и 
внешних войн и хаоса, (китайское) государство не является результатом создания некой новой структуры, на месте неоднократно распадавшейся на каждом этапе истории, а государство, которое всегла формировацось в результате возрождения того, что существует вечно.

Успешно интегрируясь в межАународную экономическую систему, сопротивляясь политической и идеологической интеграции, Китай отвергает исключительность ЗапаАа в рамках как официальной внешнеполитической доктрины, так и академических дебатов, и преАлагает свои собственные альтернативы в контексте межАународного порядка: «баланс межАу великими Аержавами» вместо «гегемонии ЗапаАа», «социализм», ориентированный на государство» вместо «капитализма», «авторитаризм» вместо «демократии» и предпочтение Аругих форм прав ения (Mazarr, Heath \& Cevallos, 2018). ОАнако Ажонстон (2013) утверждает, что Китай является державой не «ревизионистской», а державой «статус-кво». Тем не менее, согласно Аругим наблюдениям, Китай пытается «разрушиты» международный порядок, основанный на гегемонии США (Nathan, 2016; Pillsbury, 2015; Jacques, 2012; Christensen, 2016). Аругая группа исследователей задается вопросом, есть Аи у Китая желание и способность перестроить установившийся мировой порядок. В этом контексте подчеркивается, что Китай явцяется «ограниченной державой», то есть актором, Аействующим в соответствии с пассивным и ориентированным на узкие интересы подходами (Shambaugh, 2014; Swaine, 2010; 2016). Тем не менее, уровень взаимозависимости, сложившегося межлу Китаем и остальным миром в результате глобализации показывает, что Китай, включенный в существующую систему, не будет пытаться разрушать ее. На самом деле глобальный подъем Китая стац возможным благодаря этой системе. Кроме того, хотя возвышающийся Китай преуспел в выдвижении своих альтернатив, взяв на себя инициативу по установлению нового регионального порядка путем создания новых институтов и инициатив, не означает свержения существующей системы (Jones \& Zeng, 2019). Такое понимание намерений Китая вылилось в интерпретацию, рассматривающую Китай как «удовлетворенная сила».

На фоне такого разнообразия мнений, текущую митературу можно разделить на Аве категории. С одной стороны, утверждается, что подъем Китая неизбежно приведет к соперничеству великих Аержав (Mearsheimer, 2001; 2014; Jacques, 2012), с Аругой стороны, утвержАается, что такое развитие немыслимо в рамках нынешней межАународной системы (Mahbubani, 2018; Etzioni, 2016). Если одним из основных особенностей периода усиления глобализации после окончания холодной войны был симбиоз («кимерика») межАу Китаем как возвышающейся державой и США, как утвердившегося гегемона, то с начала 2000-ых годов китайско-американское противостояние стало наиболее явной тенденцией межАународных отношений, с кульминацией уровня напряженности в рамках текущего эпидемического кризиса. Принято считать, что это противостояние станет определяющим фактором динамики мира и войны в международных отношениях в среднесрочной перспективе (Аукьянов, 2020).

ГАобальный подъем Китая расценивается как феноменом исторического значения равносильный процессам конца ХХ-го века, которые имели Аолгосрочные последствия Аля мировой системы в целом, а именно падение Берлинской стены, крах Восточного блока и распаА СССР, положившие конец холодной войне и биполярному миропорядку. Тем не менее, процесс возвышения Китая и его последствия Аля мировой системы в отличие от вышеупомянутых переломных событий 1990-ых годов не привели к полномасштабным концептуальным разработкам в теории международных отношений. Так, исторические последствия революционной трансформации мирового порядка в направлении однополярности стали предметом глубоких теоретических Аискуссий и ревизий траАиционных подходов и пониманий в Аисциплине межАународных отношений, известных под общим названием «межпарадигмальный спор», наиболее интенсивная разработка которого произошло с начала 1990-х годов (Waever, 1996; Katzenstein \& Sil, 2008). В этом отношении следует отметить, что исторический феномен подъема Китая не приве к пересмотру устоявшихся парадигм в теории международных отношений (Рan \& Kavalski, 2018, 290).

Точно так же, как окончание холодной войны не только устранило биполярное противостояние за глобальное Аоминирование, но и привело к более глубоким послеАствиям Аля мировой системы в широком смысле, феномен подъема Китая, с которым мы сталкиваемся сегодня, не сводится Аишь к росту вАияния одного государства в сравнении с устоявшимися державами мировой системы. Трансформация внешнеполитического поведения Китая, а также процесс его глобального возвышения в целом, явАяется Аовольно сложным явлением, которое 
несет с собой более широкие политические, экономические и социальные изменения с точки зрения межАународной системы и порядка как на глобальном, так и на региональном уровнях. Следовательно, глобальное возвышение Китая вызывает необходимость теоретизирования в более широких перспективах и альтернативных рамках. В этом смысле в различных исследованиях подчеркивается, что подъем Китая представ яет собой онтологическую и эпистемологическую проблему, требующую пересмотра существующих парадигм, и что теоретизирование данного явления должно осуществляться вне рамок традиционных подходов (Acharya \& Buzan, 2017; Pan \& Kavalski, 2018). Аругими словами, в контексте теоретизации подъема Китая текущие усилия концептуальных разработок, основанных на таких классических парадигмах и учениях, как реализм, Аиберализм, конструктивизм, сводятся Аишь к применению и тестированию своего объяснительного аппарата и потенциала в отношении раскрытия и описания внешнеполитического поведения Китая, а также последствий его возвышения на глобальный или региональный порядок. Этот тип общепринятого (традиционного) теоретизирования, ограничивается установлением общих особенностей подъема Китая, Аругими словами, остается по большому счету описательным конструктом, которое не рассматривает подъем Китая как явление, «производящее теорию» (Pan \& Kavalski, 2018, 290-291).

Учитывая недостаточность/ограниченность объяснительного потенциала традиционных теорий межАународных отношений в поисках подходящей теоретической основы осмысления китайской внешней политики и глобального подъема подчеркивается необходимость в синтезирующих разработках, межпарадигмальных и эклектических подходах, которые могут инициировать новые дискуссий о сущности власти и ее трансформации (Пан, 2014, 388). Теория перехода власти (Lemke, 2003; Lemke \& Reed, 2001; Kim \& Gates, 2015), теория английской школы межлународных отношений (Аиберальный реализм) (Buzan, 2010; 2018; Schneider, 2014; Kirsher, 2010) и неоклассический реализм (Wohlforth, 1993; Rose, 1998; Taliaferro, 2006; Schweller, 2006; Rathbun, 2008) выступают ведущими теоретическими подходами, широко используемыми в рамках экцектического анализа.

С точки зрения поиска теоретической основы понимания внешней политики Китая и его глобального возвышения в этой части статьи будут обсужАаться основные тезисы вышеупомянутых традиционных и эклектических подходов к внешнеполитическому повеАению Китая в целом и к его глобальному подъему в частности.

\section{Конвенциональное теоретизирование и внешняя политика Китая}

Сторонники неореализма подчеркивают, что возвышение Китая неминуемо приведет к нестабильности и конфликтному соперничеству межАу великими Аержавами в сфере безопасности, основываясь на исторических примерах соперничества великих держав межАу возвышающейся державой и ослабевающей установленной державой (Friedberg, 1993). В этом контексте Миршаймер (2014; 2016; 2018; 2019), наиболее влиятельный сторонник структурного реализма, утверждает, что мирный подъем Китая невозможен, и проводит параллели между поведением растущего Китая и гегемонистской мощь США. Так, согласно неореализму, США сохранят свою решимость помешать Китаю Аоминировать в Азии, а также в остальных частях мира. Аругими словами, если Китай продолжит наращивать свою мощь, США будут стремиться к большему слерживанию и контролю Китай. Цель США - сбалансировать возвышающую мощь Китай, и Аействия по Аостижению этой цели вкАючают подАержание хороших отношений с наиболее сильным соседями Китая, такими как Индия.

С точки зрения неореализма, хотя действия США и их союзников в Азии, направленные на сдерживание Китая, преподносятся как оборонительные, они будут восприняты Китаем как агрессивные. Точно также, хотя Китай старается представить свое возвышение как мирный (оборонительный) процесс, он булет воспринят установленным гегемоном как агрессивный вызов. Следовательно, хотя экономическая и военная взаимозависимость между США и Китаем углубляется, продолжающийся экономический и военный рост Китая приведет к усилению конкуренции и противостояния между Авумя державами. Считается, что подобно тому, как США исключили европейские великие державы из Западного полушария в XIX веке, Китай, как растущая держава, будет пытаться Аистанцировать США от Азиатско-Тихоокеанского региона («китайская доктрина Монро») (Mearsheimer, 2014). 
Таким образом, с точки зрения неореализма развивающийся Китай может изменить геополитическую структуру Восточной Азии (Kirshner, 2010, 59-60). В этой ситуации утвержАается, что обострение конкурентных отношений межАу США, которые стали еАинственной сверхлержавой межАународной системы после холодной войны, и растущим Китаем приведет к так называемому феномену «ловушки Фукидида» (Allison, 2017).

Согласно неолиберальной парадигме, Аля которой межАународные институты и их влияние на внешнюю политику считаются важной переменной, Китай с его авторитарной системой, в которой институциональные механизмы слержек и противовесов сосредоточены в одном центре, как не парадоксально, может превзойти демократии в краткосрочной перспективе именно благодаря такой системе. ОАнако Аиберальная параАигма считает, что в Аолгосрочной перспективе Китай может стать надежным партнером Аля сотрудничества Аля ЗапаАа, если он будет двигаться к развитию Аемократических институциональных механизмов сдержек и противовесов и системы подотчетности. В этом контексте Най (2010), опровергая тезис о неизбежности конфликта как следствие возвышения Китая, утверждает, что решение экологических, финансовых и других глобальных проблем не будет Аостигнуто без конструктивной вовлеченности Китая. Поэтому не конфронтация, а примирение, сотрудничество и углубление взаимозависимости должно стать тем руслом, в которое следует направить процесс возвышения Китая.

Подчеркивая увеличение роли Китая в нынешней международной системе вследствие непрерывного и беспрецелентного экономического роста, Фукуяма (2016) утверждает, что политическая система Пекина коренным образом отличается от тоталитаризма ХХ-го века, поскольку экономический и политический подъем Китая не явцяется вызовом нынешнему межАународному порядку. В противовес пессимистическим прогнозам неореалистов, неолиберальная парадигма рассматривает значение глобального возвышения Китая в контексте институтов, правиц и норм Аиберацьного межАународного порядка. В этом отношении считается, что подъем Китая был возможен благодаря миберальной межАународной системе, которая считается еАинственным Аействующим и Аоминирующим порядком в эпоху после холодной войны. Сторонники глоб̆льного миберализма подчеркивают, что возможности Китая по реорганизации международного порядка ограничены. Фактически, в результате своей политики реформ и открытости Китай глубоко интегрировался в миберальную межАународную систему. Таким образом, состояние взаимозависимости ограничивает шансы Китая стать ревизионистской силой, намеренной на коренную перестройку системы, в которой и происходит рост Китая. Приверженцы неолиберализма, которые считают сценарий изменения порядка путем обращения к механизмам жесткой силы маловероятным из-за существующей глубокой взаимозависимости, полагают, что сама по себе китайская модель (в отрыве от миберального глобального порядка) неустойчива. Аругими словами, феномен подъема Китая представляется как явление, которым можно «управ яять» через сеть Аиберальных институтов и норм (Ikenbery, 2008, 30-31).

В отличие от приверженцев неореализма, которые делают упор на категории конфликта и власти, а также неолиберализма, которые исходят из концепции общих интересов и взаимозависимости, конструктивизм подчеркивает феномен идентичности, норм и ценностей как основного детерминанта, формирующего международный порядок. Конструктивизм утверждает, что процесс формирования региональных многосторонних режимов и институтов взаимодействия служит в первую очередь конструированию политической идентичности и продвижению определенных ценностей (Vucetic \& Hopf, 2018). Взаимодействие между государствами и институтами служит конструированию и мегитимизации соответствующих внешнеполитических идентичностей. В этом контексте утверждается, что Китай пытается расширить свое взаимодействие со странами Евразии путем создания различных платформ многостороннего сотрудничества, таких как инициатива «ОАин пояс, один путь» или Региональное Всеобъемлющее Экономическое Партнерство, Аля поощрения альтернативных идеологических и нормативных систем, создания мягкой и нормативной власти Пекина и повышения Аегитимности его растущей вАасти в международном сообществе (Jones \& Zeng, 2019, 1415).

Конструктивистский подход (Ноpf, 2009; 2016) в контексте теоретизирования глобального подъема Китая так же предполагает, что экономическая взаимозависимость может предотвратить конфликт великих держав. Основная идея заключается в том, что тот факт, что Китай возвышался в межАународной системе после холодной войны, в которой Аоминировали миберальные ценности, на самом деле показывает, что Пекин интегрирован в эту систему. Таким образом, 
уровень экономической, торговой и финансовой интеграции между растущим Китаем и нынешними (и находящимися в упадке) великими державами в рамках киберального порядка указывает на то, что этот переход власти будет происходить в условиях мирного соревнования и не приведет к войне великих держав (Mahbubani, 2020). Более того, это показывает, что Китай, вовлеченный во многие институты Аиберального межАународного порядка и принявший его нормы, преуспел в процессе «социализации», которому конструктивизм приАает большое значение (Johnston, 2007). В этом контексте подъем Китая рассматривается как возвращение к нормальности, особенно в контексте регионацьного порядка (Kang, et al., 2008). Так, изоляция Китая от внешнего мира, начатая с краха империи и продоцжавшаяся вплоть до эпохи реформ и открытости конца 1970-х годов сменилась приоритетностью регионального экономического сотрудничества и торговых отношений, что фактически означало возвращение к естественному состоянию

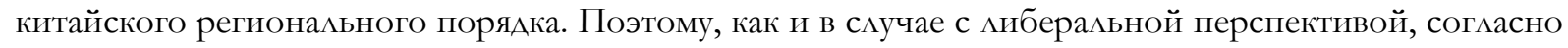
конструктивизму, подъем Китая следует рассматривать как фактор стабильности и мира, а не как конфликта с точки зрения региона и мира (Kang, et al., 2008).

\section{Эклектичное теоретизирование и внешняя политика Китая}

Выше мы установили, что в теоретических дискуссиях о намерениях возвышающегося Китая Аоминируют два аргумента: первый основан на категории силы и подчеркивает, что Китай имеет тенденцию к ревизионизму; второй исходит из категории взаимозависимости и подчеркивает, что возвышающийся Китай удовлетворен нынешней системой. ОАнако существует третья миния аргументации, которая подчеркивает их проблематичность и недостаточность Аля объяснения нынешнего подъема Китая. Особенность, которая отличает Китай как возвышающуюся державу, заключается в том, что его видение международного порядка и своего места в нем изменялось в историческом контексте. Аиапазон смены такого видения менялся от Китай как своего рода «обособленного мира», существующего отАельно от общей системы межАународных отношений Ао Китая, которому присущи тенденции к интеграции в международную систему в определенный периол истории (Legro, 2007, 516). Таким образом, ревизионистский взгляА на структуру и принципы системы временами уступац место одобрению и принятию существуюих норм и правил игры. В этом плане поворот к илее интеграции с глобальной системой начался с периода экономических реформ и открытости конца 1970-х годов.

Тем не менее, в дополнении к вариативности взглядов на международную систему Китай предлагает своеобразную модель развития. Эта модель, определяемая как своего рода «Пекинское соглашение», основана на сильной стратегии развития и роста и суверенитете, контролируемом государством. В контексте внешней политики Китай основан на трех основных принципах: притязание на региональную власть, признание превосходства Китая наА сосеАними странами и гармоничный порядок сосуществования, основанный на предылущих Авух принципах. По сути, эти принципы яв яюются проекцией пацифистской Аинии конфуцианской Аоктрины на сегодняшнее видение внешней политики Китая. Внешнеполитическое видение, основанное на этих принципах по своей природе, рассматривает межАународную систему как иерархию, в которой Китай находится на вершине, а остальные государства подчиняются или «знают свое место» (Allison, 2017).

Теории английской школы международных отношений и неоклассического реализма занимает важное место среди подходов, преАлагающих альтернативную синтезирующую теоретическую рамку, учитывающую различия в контексте вышеупомянутых исторических, структурных и идейных основ глобального подъема Китая и его внешней политики в целом.

По сравнению с традиционными подходами теория английской школы Аает возможность преодолеть узкие рамки основных теорий международных отношений и рассматривает феномен подъема Китая вне теоретической Аилеммы, основанной на альтернативности войны и мира, а именно конкурирующие позиции реализма, предрекающего противостояние великих Аержав, и миберализма, предполагающего возможность преодоления такого противостояния путем усиления глобальной интеграции (Dian \& Menegazzi, 2018, 3-4).

Разделение идеального типа международного порядка на солидаристский и плюралистический, предлагаемое теорией английской школы, важно Аля анализа роли Китая в современном региональном и глобальном порядке и А^я понимания нормативной ориентации 
Китая. Попытки Пекина бросить вызов и изменить структуру межАународного порядка можно понимать как попытку противостоять элементам солиАарности в межАународном порядке и подтвердить элементы плюралистического порядка. Основываясь на плюралистическом видении, китайская внешнеполитическая идентичность и поведение противостоят внеАрению солиларистских элементов порядка в межАународную систему (Buzan, 2018).

Преодолевая споры межАу неолиберализмом и неореализмом относительно сути подъема Китая в контексте межАународной системы, английская школа утвержАает, что Аанный процесс протекает как в рамках «перехода власти» (что означает перераспределение материальной власти), так и «смены порядка» (что означает пересмотр нормативного содержания регионального и глобального порядка). В этом контексте Китай может продвигать свои собсственные нормы и альтернативные ценности в отношении кАючевых институтов межАународного сообщества ровно так же, как он подвергаться процессу социализации, который преАусматривает интернализацию норм и правил международного порядка. Аиалектика неореализма и неолиберализма, варьирующаяся межАу усвоением и отрицанием ценностей нынешней системы, остается вне поля зрения английской школы (Buzan, 2010). В этом подходе утвержАается, что взаимодействие межАу восходящей и нисходящей силой происходит как взаимная социализация. Так, хотя Китай социализирован в соответствии с нормами и институтами межАународного порядка, возглав яемого Западом, он также имеет возможность изменять нормативные и институциональные основы порядка на региональном и глобальном уровнях, не разрушая данный порядок. Аругими словами, подъем Китая, предлагающего как структурную, так и идейную альтернативу существующему межАународному порядку через инициативу «ОАин пояс, один путь» и Аругие институциональные структуры, осуществляется в соответствии с преАписаниями ЗапаАа (Mahbubani, 2018; 2020).

Западный анализ подъема Китая часто использует неореалистическую аналитическую основу и рассматривает Китай как возвышающуюся державу в анархической международной системе (Sorensen, 2013, 367). Как мы рассмотрели выше, в контексте объяснения внешней политики Китая неореализм рассматривает системные факторы (анархию и полярность) как главный детерминант, уделяя ограниченное внимание внутренним факторам. Отправной точкой анализа, основанного на неоклассическом реализме, является утвержАение, что возвышающийся Китай не обязательно Аемонстрирует ревизионистское внешнеполитическое поведение, как утвержАается в агрессивном реализме. Характер внешней политики Китая определяется конкретными внутренними и внешними условиями, с которыми сталкивается Пекин. Аругими словами, неоклассический реализм акцентирует свое аналитическое внимание не на вопросе ревизионизма как такого, а исследует, какие именно условия приводят к тому, что можно было бы назвать ревизионистским или статус-кво поведением во внешней политике Китая. В этом контексте подчеркиваются Ава важных внутренних элемента, такие как «легитимность через исполнение внутренних заАач» и «национализм».

Китайский национализм не явАяется монотонным явлением, поскольку он подпитывается чувством исторической гордости, связанной с успехами нынешнего Китая в мировой экономике, так и с исторической памятью о «столетии унижения». Национализм, как проявление «Авойной» идентичности (Аихотомия внутренней и внешней слабости и силы) как на уровне политической власти, так и на уровне общества в целом, является фактором, влияющим на восприятие роли Китая в мире и в развитии международной системы (Sorensen, 367-368). Политическая власть в Китае всегАа использовала национализм Аля обеспечения внутренней социальной и политической стабильности и обоснования внешнеполитических действий. ГАавный аргумент китайского национализма состоит в том, что только могущественный Китай во главе с Коммунистической партией может вернуть себе заслуженный международный статус и уважение, которая позволит Китаю противостоять внешним силам, намеренным препятствовать его развитию. Китайский национализм, которому присуща нисходящая структура развития, явАяется, таким образом, частью усилий Коммунистической партии Китая по обретению Аегитимности с помощью Аостижений в экономической сфере и политического Аискурса, сконструированного вокруг успехов в обеспечении внутреннего процветания и стабильности (Sørensen, 376).

Тем не менее, согласно неоклассическому реализму, внешнеполитическая стратегия Китая определяется как внутренними переменными, так и внешней динамикой, такой как стратегическое взаимодействие с Аругими великими Аержавами и соседними странами, и национальными 
интересами. Во-первых, подъем Китая происходит в однополярной системе, в которой Аоминируют Соединенные Штаты, а это означает, что Китай неизбежно столкнется с усилиями самой могущественной страны мира по сдерживанию Китая. Кроме того, Аругие крупные Аержавы Азиатско-Тихоокеанского региона, такие как ИнАия и Япония, являются странами-союзниками США и подлерживают их в усилии стратегического сдерживания Китая. Во-вторых, как развивающаяся держава на море и на суше Китай также противостоит многим своим соседям, включая средние и малые державы. По этой причине его взаимодействие как с великими Аержавами, так и с соседними странами является элементами, которые формируют внешнеполитические интересы и поведение Китая (Danner, 2018).

Национальные интересы Китая также являются результатом стратегического взаимодействия. В этом контексте изменение национальных интересов Китая определяется не внутренними потребностями, но и межгосударственными отношениями, структурой межАународного порядка, стратегическими предпочтениями Китая и реакцией сосеАних стран на эти преАпочтения. В этом контексте указывается на историческое разделение внешнеполитических интересов Китая на три качества: оборонительное (Китай, изолирующий себя от внешнего мира), конструктивное (Китай, интегрирующийся в глобальный мир) и агрессивный (Китай, который стремится изменить мир вне себя в соответствии со своими собственными интересами). (Ye, 2019, 88-100).

Каковы внешнеполитические намерения и интересы Китая и каково видение мирового порядка и его места в этом порядке? Фактором, определяющим текущую позицию Китая в межлународном порядке, являются его национальные интересы и его видение наиболее эффективных способов достижения этих интересов. С начаца 2000-х годов Китай сосредоточиц внимание на трех основных национальных интересах: безопасность, суверенитет и развитие.

ОАна из основных функций китайского режима по предотвращению всех вилов внутренних и внешних угроз интересам безопасности состоит из Авух основных компонентов: национаАьная безопасность и обеспечение непрерывности политической системы. Приоритетом Аля китайского руководства является увековечение положение КПК как единственной политической силы. Поэтому Аюбая попытка подорвать мегитимность партии воспринимается как угроза. С 1970-х годов КПК постепенно отошла от прежнего акцента на социалистическую идеологию к пониманию экономического роста и «хорошего» управ ения как источника мегитимности. Этот переход к подходу «легитимности, основанной на результатах» (Sorensen) начал заменять марксистскую илеологию и менинскую политику, обоснованность которых ставится под сомнение (Mazarr, et al., 2018; Scobell, et al., 2020). В контексте суверенных интересов ключевым компонентом является обеспечение суверенитета наА всей территории в пределах границ Китая и защита региональной целостности, вкАючая морские и сухопутные границы. В контексте этой цели, которая описывается как постоянный национацьный интерес, Аюбая деятельность сепаратистских сил Тайваня, Восточного Туркестана и Тибета воспринимаются как угроза национальному единству и безопасности (Scobell, et al.). В контексте интереса к развитию ключевым компонентом явАяется необходимость обеспечения доступа к природным ресурсам и рынкам, увеличение влияния и присутствия Китая в регионах, где расположены трубопроводы и маршруты стратегического значения, обеспечивающие Аоступ этих ресурсов на мировые рынки. Следовательно, возможная нестабильность в этих регионах представ яет собой наиболее серьезную угрозу интересам Китая в области развития (Mazarr, et al.; Scobell, et al., 18-19).

Теория «перехода власти», разработанная в 1950-х годах А. Ф. К. Органским и предлагающая иной взгляд на вопросы война и мира, сотрудничества или конфликта межАу великими державами, вышла на первый план в контексте дискуссий о том, какие изменения повлечет за собой феномен поднимающейся китайской мощи в структуре и принципах функционирования межАународной системы. Основываясь на теории перехода вцасти, основанной на представцении о том, что приближение возвышающейся силы к паритету (равенству) в отношении с установленной силой (гегемоном) непременно влечет за собой дестабилизацию межАународной системы с вероятностью военного столкновения, утвержАается, что рост относительной мощи и влияния Китая в отношении США приведет к возражению против текущего межАународного поряАка и к попыткам изменить правица, на которых зиждется Аанная система. В этом отношении существует предположение, что Пекин стремится изменить глобальное управление и преобразовать существующую межАународную систему в направлении более полного отражения его собственных 
ценностей, интересов и растущей роли. По большому счету эта точка зрения совпадает с вышеуказанной обширной Аитературой, в которой подчеркивается, что растущая мощь возвышающегося Китая и, следовательно его растущие возражения против существующего порядка неизбежно приведут к силовому соперничеству с США, и что Китай не будет продолжать возвышаться мирным путем (Allison, 2017; Brzezinski, 2014; Mearsheimer, 2014).

Согласно теории перехода власти, если растущий Китай превзойдет нынешнюю Аоминирующую в системе державу, не требуя радикальных изменений в контексте структуры и норм международной системы, предотвращение столкновения великих держав будет возможным. Утверждается, что такая ситуация преАставляет собой сценарий перехода власти, который наблюдался ранее в истории международных отношений. Так США, которые достигли Аоминирующего положения в системе вместо Великобритании, возвышались не в результате войны, а вследствие стратегии растущей Аержавы, занимающей «удовлетворенную» или не ревизионистскую позицию в контексте меняющегося международного порядка. При этом ревизионистская позиция возвышающейся Германии привела к Авум великим войнам в мировой истории. Аругими словами, изменение структуры международного порядка будет зависеть от консенсуса межАу восходящей и нисходящей Аержавами относительно структуры и принципов функционирования порядка (Lemke \& Lemke, 2003, 224; Shifrinson, 2018). Таким образом, согласно теории перехода власти, степень удовлетворенности возвышающегося Китая нынешним порядком, Ааже при условии максимальной приближения к потенциалу США, устранит вероятность столкновения великих держав в новом тысячелетии.

\section{Закиючение}

Внешняя политика Китая и его стратегия подъема характеризуются совокупностью преемственности и изменений в континууме. В Аанной статье была предпринята попытка обосновать идею о том, что внешнеполитическая идентичность и поведение Китая, как возвышающейся силы, определяется его историческим прошлым. Как внутриполитический нарратив, так и внешнеполитическая стратегия глобального возвышения Китая, существующего и развивающегося «в тени своего прошлого», содержит множество ссылок на исторический опыт китайской нации, наиболее полно проецированных в концепции «китайской мечты», осуществление которой, как преАставляется, АОАжно привести к «великому национальному возрожАению» Китая и катайской нации. В этом контексте традиция установления связи межАу внешнеполитическим поведением (и целями) Китая и его историей вновь обрела значимость.

ИзАожив в ретроспективном порядке процесс развития внешнеполитический подходов Китая с периода учреждения КНР вплоть до сегодняшнего Аня, статья также преАприняла попытку резюмировать существующие концептуальные подходы к теоретизации внешней политики и феномена глобального возвышения Китая, акцентируя внимание на Аихотомии ревизионизма и приверженности статус-кво в отношении структуры мировой системы и разАеляя существующие теоретические разработка на две категории: конвенциональное и эклектичное теоретизирование.

\section{Ethical Declaration}

In the writing process of the study titled "Theorizing Chinese Foreign Policy: Conceptual Tenets in Historical Continuum", there were followed the scientific, ethical and the citation rules; was not made any falsification on the collected data and this study was not sent to any other academic media for evaluation. Since the document is examined in this study, there is no requirement for an ethics committee decision.

\section{References}

Acharya, A., \& Buzan, B. (2017). Why is there no non-western international relations theory? Ten years on. International Relations of the Asia Pacific, 17(3), 1-30.

Allison, G., Robert D. Blackwill, Ali Wyne (2012). The Grand Master's Insights on China, the United States, and the World. Cambridge: The MIT Press.

Allison, G. (2017). Destined to war. Can America and China escape thucydides's trap? New York: Houghton Mifflin Harcourt.

Bekkevold, J. I. \& Ross, R. S. (2016). Introduction. China's New Leadership in Domestic and International Politics. In R. S. Ross \& J. I. Bekkevold (Eds.). China in the Era of Xi Jinping. Domestic and Foreign Policy Challenges (pp. 2145). Washington, DC: Georgetown University Press.

Bijian, Z. (2005) China's Peaceful Rise to Great-Power Status. Foreign Affairs. Retrieved from https://www.foreignaffairs.com/articles/asia/2005-09-01/chinas-peaceful-rise-great-power-status 
Bo, Z. (2016). China's Fifth-Generation Leaders. Characteristics of the New Elite and Pathways to Leadership. In R. S. Ross \& J. I. Bekkevold (Eds.). China in the Era of Xi Jinping. Domestic and Foreign Policy Challenges (pp. 47-118). Washington, DC: Georgetown University Press.

Breslin, S. (2010). China's emerging global role: dissatisfied responsible great power, Politics, 30(1), 52-62.

Brzezinski, Z. (1998). The Grand Chessboard: American Primacy and its Geostrategic Imperatives. New York: Basic Books.

Brzezinski, Z. (2014). Can China avoid the Thucydides trap? New Perspectives Quarterly, 31(2), 31-33.

Buzan, B. (2001). The English School: An Underexploited Resource in IR. Review of International Studies, 27(3), 471-488.

Buzan, B. (2004). From International to World Society? English School Theory and the Social Structure of Globalization. Cambridge: Cambridge University Press.

Buzan, B. (2010) China in International Society: Is 'Peaceful Rise' Possible? The Chinese Journal of International Politics, $3(1), 5-36$

Buzan B. (2014). The 'Standard of Civilisation' as an English School Concept. Millennium, 42(3), 576-594.

Buzan, B. (2018). China's rise in English school perspective. International Relations of the Asia-Pacific. 1-28

Callahan, W. (2005). How to understand China: the dangers and opportunities of being a rising power. Review of International Studies, 31, 701-714.

Christensen, T. (2016). The China Challenge: Shaping the Choices of a Rising Power, New York: W. W. Norton.

Danner, L. (2018). China's Grand Strategy Contradictory Foreign Policy? London: Palgrave Macmillan

Dian, M. \& Menegazzi, S. (Eds.) (2018). New Regional Initiatives in China's Foreign Policy. The Incoming Pluralism of Global Governance. London: Palgrave Macmillan.

Dunne, T. (1998). Inventing International Society: A History of the English School. Houndmills: Palgrave

Etzioni A. (2016). How aggressive is China? The Korean Journal of International Studies, 14(2), 291-307.

Fallon, T. (2014). China's pivot to Europe. American Foreign Policy Interests, 36(3), 175-182.

Fallon, T. (2015). The New Silk Road: Xi Jinping's Grand Strategy for Eurasia, American Foreign Policy Interests, 37(3), 140-147.

Feng Zhu \& Peng Lu (2015). Be strong and be good? Continuity and change in China's international strategy under Xi Jinping. China Quarterly of International Strategic Studies, 1(1), 19-34.

Fingar, T. (Ed.) (2016). The New Great Game. China and South and Central Asia in the age of Reform. Stanford: Stanford University Press.

Fairbank, J. K., (1969). China Foreign Policy in Historical Perspective," Foreign Affairs. Retrieved from https://www.foreignaffairs.com/articles/asia/1969-04-01/chinas-foreign-policy-historical-perspective

Fairbank, J. K. (Ed.) (1968). The Chinese World Order: Traditional China's Foreign Relations. Cambridge: Harvard University Press.

Foulon, M. (2015). Neoclassical Realism: Challengers and Bridging Identities. International Studies Review, 17, 635-661

Fravel, M. (2010). International Relations Theory and China's Rise: Assessing China's Potential for Territorial Expansion. International Studies Review, 12, 505-532.

Fukuyama, F. (2016). Reflections on Chinese governance. Journal of Chinese Governance, 1(3), 379-391.

Garver, J. W. (2016). China's Quest: The History of the Foreign Policy of the People's Republic of China, New York: Oxford University Press.

Hopf, T., Bentley, A. (Eds.) (2016). Making identity count: building a national identity database. Oxford: Oxford University Press.

Hopf, T. (2009). Identity relations and the Sino-Soviet split. In A. R., Herrera \& R. McDermott (Eds.). Measuring Identity (pp. 279-315) Cambridge: Cambridge University Press.

Ikenberry, J. (2008). The Rise of China and the Future of the West: Can the Liberal System Survive? Foreign Affairs, 87 (1), 23-37.

Jacques, M. (2012). When China Rules the World: The End of the Western World and the Birth of a New Global Order. Penguin Books.

Johnston, A. (2007). Social States: China in International Institutions, 1980-2000. Princeton: Princeton University Press.

Jones, L. \& Zeng, J. (2019). Understanding China's 'Belt and Road Initiative': beyond 'grand strategy' to a state transformation analysis, Third World Quarterly, 40(8), 1415-1439.

Katzenstein, P. \& Sil, R. (2008). Eclectic Theorizing in the Study and Practice of International Relations. In C. ReusSmit \& D. Snidal (Eds.), The Oxford Handbook of International Relations (pp. 109-130). Oxford: Oxford University Press.

Kang, D. (2010). East Asia before the West: Five Centuries of Trade and Tribute. New York: Columbia University Press.

Kang, Y., Lu, S. \& E. D. Brown (2008), Chinese Corporate Governance: History and Institutional Framework. Santa Monica, CA: RAND Corporation. Retrieved from https://www.rand.org/pubs/technical_reports/TR618.html.

Kim, S. (2006). Chinese Foreign Policy Faces Globalization Challenges. In A. I. Johnston \& R. S., Ross (Eds.) (2006), New Directions in the Study of China's Foreign Policy (pp. 276-308). California: Stanford University Press.

Kissinger, H. (2012). On China. New York: Penguin Books.

Kim, W. \& Gates, S. (2015). Power transition theory and the rise of China. International Area Studies Review, 18(3), 219226. 
Kugler, J. \& Organski, A. F. K. (1989). The Power Transition: A Retrospective and Prospective Evaluation. In M. Midlarsky (Ed.), The Handbook of War Studies (pp. 171-194). Boston, MA: Unwin Hyman.

Kirshner, J. (2010). The tragedy of offensive realism: Classical realism and the rise of China. European Journal of International Relations, 18(1), 53-75.

Kai, H. \& Huiyun, F. (2013), Xi Jinping's operational code beliefs and China's foreign policy, The Chinese Journal of International Politics, 6(3), 209-231.

Legro, J. (2007). What China Will Want: The Future Intentions of a Rising Power. Perspectives on Politics, 5(3), 515-534.

Lemke, D. \& Lemke, D. (2003) Power Transition Theory and the Rise of China, International Interactions: Empirical and Theoretical Research in International Relations, 29(4), 269-271.

Lemke, D. \& Werner, S. (1996). Power Parity, Commitment to Change, and War. International Studies Quarterly, 40(2), 235-260.

Lew, C. \& Leung, P. (Eds.) (2013). Historical Dictionary of the Chinese Civil War. Lanham, Maryland: The Scarecrow Press, Inc.

Lukin, A. (2020). The Russia-China entente and its future. Int Polit. https://doi.org/10.1057/s41311-020-00251-7

Mahbubani, K. (2018). Has the West Lost It? A Provocation. Allen Lane.

Mahbubani, K. (2020). Has China Won? The Chinese Challenge to American Primacy. Public Affairs.

Mazarr, M., Timothy R. Heath, and Astrid Stuth Cevallos, (2018) China and the International Order. Santa Monica, CA: RAND Corporation. Retrieved from https://www.rand.org/pubs/research reports/RR2423.html

Mearsheimer, J. (2014) Can China Rise Peacefully? The National Interest. Retrieved from https:// nationalinterest.org/commentary/can-china-rise-peacefully-10204

Mearsheimer, J. (2001) The Tragedy of Great Power Politics. W. W. Norton \& Company.

Mearsheimer, J. (2016). Benign hegemony. International Studies Review, 18 (1), 147- 149.

Mearsheimer, J. (2018). The great delusion: liberal dreams and international realities. New Haven and London: Yale University Press.

Mearsheimer, J. (2019). Bound to fail the rise and fall of the liberal international order. International Security, 43 (4), 750.

Miller, T. (2019). China's Asian Dream: Empire Building Along the New Silk Road. London: Zed Books.

Nathan, A. (2016). China's Rise and International Regimes: Does China Seek to Overthrow Global Norms? In R. S. Ross \& J. I. Bekkevold (Eds.). China in the Era of Xi Jinping. Domestic and Foreign Policy Challenges (pp. 449-525). Washington, DC: Georgetown University Press.

Nye, J. (2010). The future of American power: dominance and decline in perspective. Foreign Affairs, 89(6), 2-12.

Olimat, M. (2010). Playing by the rules? Sino-Middle Eastern relations. In S. Breslin (Ed.) (2010) Handbook of China's International Relations (pp. 177-187). London \& New York: Routledge.

Organski, A. F. K. (1958). World Politics. New York: Alfred A. Knopf.

Pan, C. (2014). Rethinking Chinese Power: A Conceptual Corrective to the 'Power Shift' Narrative. Asian Perspective, 38 (3), 387-410.

Pan, C., Kavalski, E. (2018). Theorizing China's rise in and beyond international relations. International Relations of the Asia-Pacific, 18 (3), 289-311.

Pan, Z., Chen Z. (2013) Peaceful Rise, Multipolarity, and China's Foreign Policy Line. In Inoguchi T., Ikenberry G.J. (Eds.) The Troubled Triangle. Asia Today (pp. 63-86). Palgrave Macmillan, New York.

Peter, F. (2016). Westward ho - The China Dream and "One Belt One Road": Chinese Foreign Policy Under Xi Jinping. International Affairs, 92(4), 941-957.

Peters, M. (2017) The Chinese Dream: Xi Jinping thought on Socialism with Chinese characteristics for a new era, Educational Philosophy and Theory, 49(14), 1299-1304.

Pillsbury, M. (2015). The Hundred Year Marathon: China's Secret Strategy to Replace America as the Global Superpower, New York: Henry Holt \& Co.

Rathbun, B. (2008) A Rose by Any Other Name: Neoclassical Realism as the Logical and Necessary Extension of Structural Realism. Security Studies, 17(1), 294-321.

Rolland, N. (2017). China's 'Belt and Road Initiative': Underwhelming or Game-Changer? The Washington Quarterly, 40 (1), 127-142.

Rose, G. (1998) Review: Neoclassical Realism and Theories of Foreign Policy. World Politics, 51(1), 144-172.

Roett, R. (2010). China's deepening ties with Latin America: a work in progress. In S. Breslin (Ed.) Handbook of China's International Relations (pp. 200-208). London and New York: Routledge.

Suettinger, R. (2004). The Rise and Descent of "Peaceful Rise". Retrieved from https://www.hoover.org/research/rise-and-descent-peaceful-rise

Shambaugh, D. (2005). The Rise of China and Asia's New Dynamics. In D. Shambaugh, (Ed.) Power Shift. China and Asia's New Dynamics (pp. 1-20). Berkeley: University of California Press.

Shambaugh, D. (2014) The Illusion of Chinese Power. Brookings Institution. Retrieved from https://www.brookings.edu/opinions/the-illusion-of-chinese-power/

Shambaugh, D. (2013). China Goes Global. The Partial Power. New York: Oxford University Press.

Shambaugh, D. (2016). China's future. Cambridge: Polity Press.

Scobell, A., Edmund J., Cortez, A. Cooper, I., Sale, L., Chad, J. R., Ohlandt, E. (2020). China's Grand Strategy. Trends, Trajectories, and Long-Term Competition. RAND Corporation, Santa Monica, California. 
Scobell, A. (2020) Something Old, Something New Continuity and Change in China's Foreign Policy. RAND Corporation. Retrieved from https://www.rand.org/pubs/testimonies/CTA774-1.html

Swaine, M. (2016) Chinese Views on Global Governance Since 2008-2009: Not Much New, China Leadership Monitor, Retrieved from https://carnegieendowment.org/2016/02/08/chinese-views-on-global-governance-since2008-9-not-much-new-pub-62697

Swaine, M. (2010), Perceptions of an Assertive China. China Leadership Monitor, 32 (1).

Shifrinson, I. (2018). Rising Titans, Falling Giants. How Great Powers Exploit Power Shifts. Ithaca and London: Cornell University Press.

Sorensen, C. (2013). Is China Becoming More Aggressive? A Neoclassical Realist Analysis. Asian Perspective, 37 (3), 363-385.

Shaohua, H. (2006), Revisiting Chinese Pacifism. Asian Affairs, 32(4), 256-278.

Taliaferro, J. W. (2009). Neoclassical Realism and Resource Extraction: State Building for Future War. In S. Lobell, N. Ripsman, \& J. Taliaferro (Eds.) Neoclassical Realism, the State, and Foreign Policy (pp. 464-495). New York: Cambridge University Press.

Taylor, I. (2010). A challenge to the global liberal order? The growing Chinese relationship with Africa. In S. Breslin (Ed.) Handbook of China's International Relations (pp. 187-199). London and New York: Routledge

Torbakov, I. (2015). Managing Imperial Peripheries: Russia and China in Central Asia. In T. Fingar (Ed.) The New Great Game. China and South and South and Central Asia in the age of Reform (pp. 646-729). Stanford: Stanford University Press.

Vucetic, A., Hopf, T. (2018). The distribution of identity and the future of international order: China's hegemonic prospects. International Organization, 72 (4), 839-869.

Yan, X. (2014). From keeping a low profile to striving for achievement, The Chinese Journal of International Politics. 7(2), 153-184.

Ye, X. (2019). Rediscovering the Transition in China's National Interest: A Neoclassical Realist Approach. Journal of Current Chinese Affairs, 48(1), 76-105.

Yilmaz, S. (2015) China's Foreign Policy and Critical Theory of International Relations. Journal of Chinese PoliticaScience. DOI 10.1007/s11366-015-9357-z

Wohlforth, W. (1993). The Elusive Balance: Power and Perceptions During the Cold War. Ithaca: Cornell University Press.

Waever, O. (1996) The Rise and Fall of the Inter-Paradigm Debate. In S. Smith, K. Booth, \& M. Zalewski (Eds.). International Theory: Positivism and Beyond (pp 149-185). Cambridge: Cambridge University Press.

Wen, J. (2004). Carrying Forward the Five Principles of Peaceful Coexistence in the Promotion of Peace and Development. Speech by Premier of the State Council of the People's Republic of China at Rally Commemorating the 50th Anniversary of The Five Principles of Peaceful Coexistence. Retrieved from http://tr.china-embassy.org/eng/xwdt/t140777.htm

Xuetongi, Y. (2013). Pre-Qin Philocpeдинsophy and China's Rise Today. In Y. Xuetong (Ed.). Ancient Chinese Thought, Modern Chinese Power (pp. 199-221). Princeton University Press.

Zhang, D. (2018). The Concept of Community of Common Destiny in China's Diplomacy: Meaning, Motives and Implications. Asia and the Pacific Policy Studies, 5 (2), 196-207.

Zhang, F. (2009). Rethinking the 'Tribute System': Broadening the Conceptual Horizon of Historical East Asian Politics. Chinese Journal of International Politics, 2 (4), 545-574.

Zhu, Z. (2013). Foreign Policy of the People's Republic of China. In R. K. Beasley, J. Kaarbo, J. S. Lantis, and M. T. Snarr (Eds.) Foreign Policy in Comparative Perspective Domestic and International Influences on State Behavior (pp. 118137). Los Angeles: CQ Press.

Бычкова Т. А. (2014). Страны Азии на пути от традичионого общества к индустриальному (ХVІІ - начало XX в.). [Asian countries on the way from traditional to industrial societies (17 - early 20 century).] Tомск: Издательский Аом Томского государственного университета.

Грачиков, Е. Н. (2015). Геополитика Китая: эгочентризм и пространство сетей [China's geopolitics: egocentrism and the space of networks]. Москва: Издательство «Русайнс».

Иванов, С. А. (2016). Почему коммунистический режим в Китае пережил 1989 г.? Россия и АТР, 1(1), 49-65.

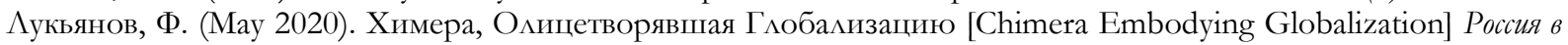
Глобальной Политике. Retrieved from https://globalaffairs.ru/articles/himera-globalizacziya/

\section{EXTENDED ABSTRACT}

The end of the Cold War and the collapse of the bipolar system of international relations resulted in a "unipolar moment" for the US as a single dominant power in the international system. However, in a relatively short period of time China as an emerging power ascended to a status of a rising power that became able to fill the power vacuum in the system. Currently, the growing presence and influence of a rising China which managed to move from the periphery of the international system to its center is evidently felt across the globe and in every dynamic of changing international relations. Accordingly, the focal point of the IR studies which have over the past thirty years been absorbed by measuring the degree and mechanisms of the international system's impact on China shifted its analytical attention toward an 
understanding of how China influences the system. However, to propose a comprehensive account of the essence of the Chinese foreign policy approach and foundational pillars of its global rise we should proceed not only from the current changing aspects of international relations but also resort to a retrospective analysis of Chinese foreign policy per se with a particular focus on the continuum of elements of constancy and change in policy approaches. Thus, the factor of history embodies an inherent characteristic of Chinese foreign policy doctrines and conceptual provisions that emerged in different periods of its historical evolution.

In other words, a major factor that indelibly influences China's foreign policy vision and behavior, as well as the ideational structure of Chinese self-perception is the factor of the past. Since the proclamation of the PRC in 1949, Chinese foreign policy has undergone significant transformations under the influence of both external and internal factors. As part of this transformation, China's foreign policy orientation and the conceptual approach has also undergone recurring revisions. Within each period of the historical evolution of China's foreign policy, its strategic approach, conceptual underpinnings, foreign policy priorities, and the vision of the international order changed in accordance with both internal and external (global and regional) variables.

This paper is an attempt to examine the historical evolution and transformation of China's foreign policy approaches, to discuss major periods of this transformation and most important provisions of the foreign policy doctrine developed within each stage. Premised on this the paper also seeks to address the projection of the main ideas and principles on the current process of China's rise with deep-rooted regional and global consequences. By retrospectively analyzing the foreign policy of China as a rising power (or as Henry Kissinger accurately put it, as a returning power) this paper tries to substantiate the idea that China's foreign policy identity and the fundamental nature of its behavior are determined by its historical past metaphorically defined as a shadow or tyranny of the past. In other words, the main notion put forward by the authors of the paper is that China's vision of the world and its place in it, as well as the entire structure of its external actorness, evolves under the influence of its history. Both the domestic political narrative and the foreign policy strategy contain numerous references to the historical experience of the Chinese nation. The most obvious manifestation of such appeal to history in China's foreign policy and its global strategy is a frequent reference to the historical experience of the "century of humiliation" in foreign policy doctrine as a whole and within Xi Jinping's concept of the "Chinese dream" in particular. Furthermore, China's global strategy which rests on this idea of the Chinese dream is believed to lead to the "great rejuvenation of the Chinese nation".

By outlining the evolution of China's foreign policy approaches in a retrospective manner this paper has also tried to summarize the existing conceptual accounts of Chinese foreign policy and the phenomenon of China's global rise. In terms of theoretical and methodological framework the paper is premised on the assertion that in consequence of the insufficiency and limited explanatory power of traditional theories of international relations there is a need for synthesizing, inter-paradigmatic and eclectic approaches in accounting for the phenomena of China's global rise and understanding its foreign policy vision. In this regard, the paper's effort to theorize China's foreign policy is carried out both within the framework of conventional theories of international relations (neorealism, neoliberalism, constructivism) and eclectic approaches (power transition theory, the English school of international relations theory (liberal realism) and neoclassical realism), which can initiate new discussions around the essence of power and its transformation. By differentiating existing theoretical approaches into conventional and eclectic theorizing paper specifically focuses on the dichotomy of "revisionism" and "adherence to the status quo" in relation to the existing structure and principles of the international system. It emphasizes that the global presence and impact of China as well as its attitude toward the structure and norms of the existing international order is conceptualized in the range of "China perceptions" oscillating between two extremes: "China as a threat" and "China as an opportunity". 